\title{
Minimization of Off-Flavor Occurrence During the Storage of Modified Atmosphere Packaged Pleurotus ostreatus
}

\author{
Eun-Kyoung Lee ${ }^{1}$, Bong-Su Noh ${ }^{2}$, and Gun-Hee $\mathrm{Kim}^{1 \dagger}$ \\ ${ }^{1}$ Department of Food and Nutrition, Duksung Women's University, Seoul 132-714, Korea \\ ${ }^{2}$ Department of Food Technology, Seoul Women's University, Seoul 139-144, Korea
}

\begin{abstract}
This study was conducted to investigate the minimization of off-flavor occurrence and the maintenance of high quality in modified atmosphere packaged Pleurotus ostreatus during the storage. There are 4 treatments used to preserve high quality and for deodonization of MAP mushroom: Artemisia princeps, Artemisia capillaries, green tea and activated charcoal. The mushrooms were packed in polyethylene film with each treatment and were stored at 5 and $20^{\circ} \mathrm{C}$. No difference was observed in weight loss, $\mathrm{CO}_{2}$ and $\mathrm{O}_{2}$ concentration, or color of mushrooms packed with or without treatment. However, the principal component analysis (PCA), electronic nose, revealed differences in off-flavor occurrence between control (MAP mushroom without treatment) and treatment groups at $5^{\circ} \mathrm{C}$. This result suggested that Artemisia princeps and Artemisia capillaries was masking the off-flavor in MAP mushroom because the unique flavor of them was strongly revealed and green tea and activated charcoal might have a role of removing the off-flavor by adsorbing ethanol and acetaldehyde, which is known to cause off-flavor. The sensory test showed that Artemisia princeps and Artemisia capillaries dough treatment inhibited microbial growth.
\end{abstract}

Key words: deodorization, Pleurotus ostreatus, Artemisia, green tea, charcoal, electric nose

\section{INTRODUCTION}

Mushrooms are widely consumed because of their unique flavor as well as plentiful nutrients such as carbohydrates, amino acids, vitamins and minerals. Also, it is reported that mushrooms can exert antioxidative activities and antimutagenicties $(1,2)$. However, mushrooms such as Pleurotus ostreatus undergo rapidly deterioration during storage and distribution. Many studies on maintaining freshness of mushrooms have been reported on modified atmosphere packaging (MAP) (3-5), controlled atmosphere (CA) (6), chill storage (7), coating treatment (8), radiation treatment (9), ozone treatment (10) and moisture absorber treatment $(11,12)$. MAP is one of the most effective and economical ways to maintain freshness $(3,13,14)$, but it can result in considerable losses of the unique flavor of mushrooms because the relatively large amounts of ethanol and acetaldehyde are produced in the film bag during storage $(15,16)$. This strong off-flavor leads to deterioration of the flavor in the fresh mushrooms. The intense modified atmosphere created anaerobic condition in the packages, which probably promoted fermentation which, in turn, induced the offflavor.

Villaescusa and Gil (17) reported that the character- istic aroma of mushrooms decreased during storage time. In addition, moderately serious off-odors were detected for mushrooms stored in PVC and LDPE packages. Lee et al. (16) also reported that the amounts of ethanol and acetaldehydes in the shiitake mushroom stored in PE film were increased proportionally to the thickness of film during the storage. Minamida et al. (15) showed that exposing the mushrooms stored in PE film in air for 6 hours decreased the off-flavor, but it brought about losses of the characteristic flavor in the mushrooms.

The off-flavors in foods may originate from environmental pollutants, the growth of microorganism, oxidation of lipids, or endogenous enzymatic decomposition (18). Many studies have been published on deodorization for removal of the odor in foods (19-22). There are the deodorization materials; $\beta$-cyclodextrin and activated charcoal as chemical materials, and green tea and Mugwort as natural materials, but little information has been published on the deodorization for MAP mushrooms. The aim of this study was to investigate the minimization of off-flavor occurrence and maintenance of high quality during the storage of Pleurotus ostreatus packaged with various treatments such as Artemisia princeps, Artemisia capillaries, green tea and activated charcoal, which are known to have deodorization effects.

'Corresponding author. E-mail: ghkim@duksung.ac.kr

Phone: +82-2-901-8496, Fax: +82-2-901-8474 


\section{MATERIALS AND METHODS}

\section{Sample preparation}

Fresh mushrooms (Pleurotus ostreatus) were obtained from a farm in Gyeonggi Province, Korea. The freshly harvested mushrooms were transported to the laboratory and were promptly placed in a cold chamber at 5 and $20^{\circ} \mathrm{C}$ until being packed.

The treatments for preserving high quality and deodorization were: Artemisia princeps (AP), Artemisia capillaries (AC), green tea (GT) and activated charcoal (CH). The dried AP, AC and GT were purchased at Kyoungdong market (herbal medicine market) in Seoul, Korea and were powdered in a blender (Chung-gye Industrial, Korea). Activated charcoal was purchased from Sigma. AP, AC and GT dough for treatment were mixed with proper ratios of distilled water (DW) according to the weight of each sample powder (AP powder : $D W=1: 3$, AC powder : $\mathrm{DW}=1: 2, \mathrm{GT}: \mathrm{DW}=1: 1.5)$. Each amount of sample was $2 \mathrm{~g}$ of $\mathrm{AP}, \mathrm{AC}$ powder and $5 \mathrm{~g}$ of GT powder, and activated charcoal, respectively to $100 \mathrm{~g}$ of mushroom. The amounts used in the treatments were selected based on a preliminary study.

\section{Packaging and storage}

The mushrooms were sorted by size and appearance. Acceptable mushrooms were selected at random and were placed into polyethylene pouches, each pouch contained $100 \pm 2 \mathrm{~g}$ of mushrooms. The polyethylene pouches were LDPE (low density polyethylene) film of 20 $\mathrm{cm} \times 30 \mathrm{~cm}, 45.33 \mu \mathrm{m}$ thickness, and $912.8 \mathrm{cc} / \mathrm{m}^{2} /$ days transfer rate (Sewang Co., Korea). Plastic cups (diameter: $5.5 \mathrm{~cm}$, height: $3.0 \mathrm{~cm}$ ) were used to hold treatments. Artemisia princeps, Artemisia capillaries, green tea dough and activated charcoal were put in the plastic cups and placed in the edge of the packaging. Packages were heat-sealed and were stored in chamber at 5 and $20^{\circ} \mathrm{C}$. Samples were evaluated after the $1 \mathrm{st}, 2 \mathrm{nd}$ and $3 \mathrm{rd}$ days of storage at $20^{\circ} \mathrm{C}$ and after the $2 \mathrm{nd}, 4$ th, 6 th and 8 th days of storage at $5^{\circ} \mathrm{C}$. The analyses were done in triplicate. Mushrooms packed without treatment were used as controls.

\section{Electronic nose analysis}

Electronic nose analysis was used to measure changes in the mushroom flavor as described through the use of PCA (principal component analysis). The electronic nose with a sensor array composed of six metal oxide sensors (Figaro Engineering Inc, Tokyo, Japan) was manufactured by Hanbit Instrument (Seoul, Korea). The injection of a gas sample was performed at the set time by opening the valve, which was controlled by computer. Data from the metal oxide sensors were also obtained via a computer. For analysis, the mushroom ( $5 \mathrm{~g})$ was placed in a $325 \mathrm{~mL}$ glass bottle sealed with polyethylene. The equilibrium time for analysis was $5 \mathrm{~min}$ in the electronic nose. All measurements were performed at $30^{\circ} \mathrm{C}$. The measurement procedures comprised of heater cleaning for $10 \mathrm{sec}$, purging the sensors and pumping clean air for $20 \mathrm{sec}$, and then headspace analysis of mushroom for $180 \mathrm{sec}$.

\section{Instrumental analysis}

The weight loss was expressed as a percentage of the initial weight at the beginning of storage. The weight loss rate (\%) was calculated using the following equation.

Weight loss rate $(\%)=\left[\left(\mathrm{W}_{1}-\mathrm{W}_{2}\right) / \mathrm{W}_{1}\right] \times 100$

$\left(\mathrm{W}_{1}\right.$ : initial weight, $\mathrm{W}_{2}$ : weight after storage)

For analysis of $\mathrm{O}_{2}$ and $\mathrm{CO}_{2}$ concentration inside film the package, oxygen analyzer (IIJIMA products M.F.G. Co. Ltd., Japan) and gas chromatography (Hewlett Packard 6890) with thermal conductivity detector (TCD) were used. Samples $(1 \mathrm{~mL})$ of the modified atmospheres within the packages were taken with a syringe through a tape. Analysis of $\mathrm{CO}_{2}$ was performed on an activated charcoal column. The measurement procedures were conducted at an injection temperature of $120^{\circ} \mathrm{C}$, oven temperature of $70^{\circ} \mathrm{C}$, detector temperature of $150^{\circ} \mathrm{C}$. The carrier gas was $\mathrm{He}(30 \mathrm{~mL} / \mathrm{min})$.

The surface color of the mushrooms was measured using a colorimeter (Minolta chromameter CR-200, Japan). Before measurement, the instrument was standardized with a white plate $\mathrm{L}=91.74, \mathrm{a}=-0.97, \mathrm{~b}=1.46$ ). Ten measurements were taken at random locations on the stem of each mushroom, and the results were expressed as Hunter b (yellowness) values.

\section{Quality evaluation}

The quality evaluation was determined by sensory evaluation. The sensory evaluation was conducted to determine microbial contamination by three trained panelists. Panelists scored each attribute on the extent of contamination on a 5-point scale; 5 point: no contamination (fresh mushroom), 4 point: contamination ratio $<10 \%, 3$ point: contamination ratio $<30 \%, 2$ point: contamination ratio $>50 \%, 1$ point: contamination ratio $>80 \%$ (contamination serious).

\section{Statistical analysis}

Statistical analysis of the data was performed using SAS software. Analysis of variance (ANOVA) with Duncan's multiple-range test was used to test the significance of differences among means. Significance was accepted at $\mathrm{p}<0.05$. 


\section{RESULTS AND DISCUSSION}

\section{Electronic nose analysis}

The electronic nose with six metal oxide sensors was used to identify off-flavor occurrence of mushrooms during storage. The data obtained from the electronic nose were used to investigate the occurrence of off-flavor for PCA (Principal Component Analysis).

In the Fig. 1, the proportion of the first principal component score was 0.847 and the second principal component score was 0.143 at $20^{\circ} \mathrm{C}$ after 1 day. The PCA plot of fresh mushrooms (before storage) was placed on the right side (positive value of the first principal component) on the other hand that of treated mushroom and control (MAP mushroom without treatment) was placed on the left side (negative value of the first principal component). No differences in occurrence of off-flavor were found between treatments and control. It was believed to be a consequence the off-flavor of MAP mushrooms being very strong regardless of treatment after 1 day. However, at $5^{\circ} \mathrm{C}$, the PCA plot of treated mushroom showed characteristic development of off-flavor at dif-
After 1 day

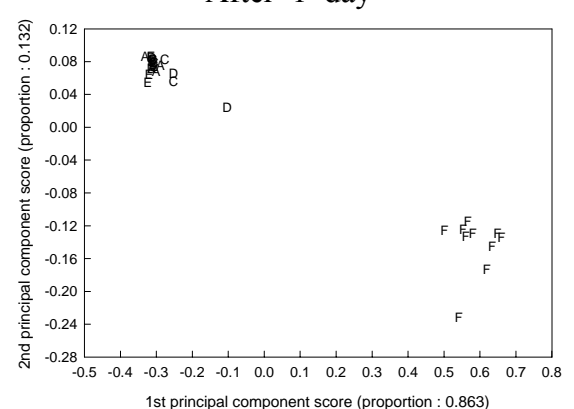

After 2 day

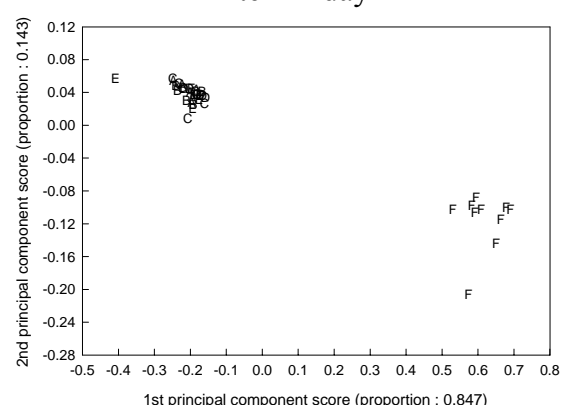

After 3 day

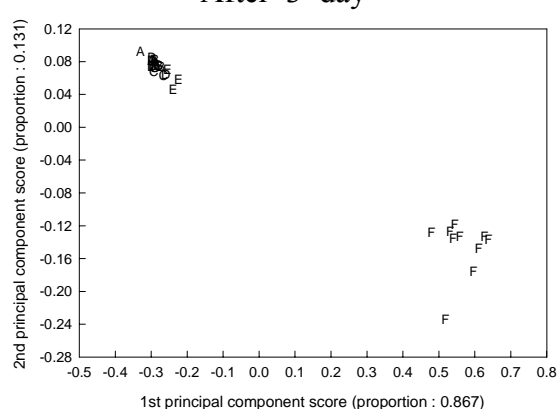

Fig. 1. Principal component analysis for Pleurotus ostreatus stored at $20^{\circ} \mathrm{C}$.

A: control (MAP mushroom without treatment), B: MAP mushroom with Astemisia princeps dough, C: MAP mushroom with Astemisia capillaries dough, D: MAP mushroom with green tea dough, E: MAP mushroom with charcoal, F: Fresh mushroom.

After 2 day

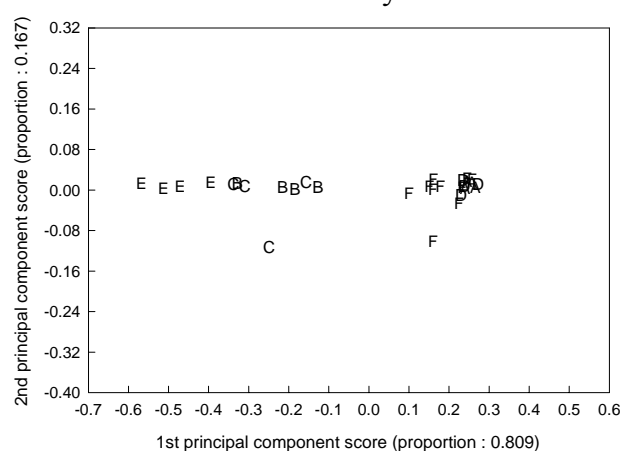

After 6 day

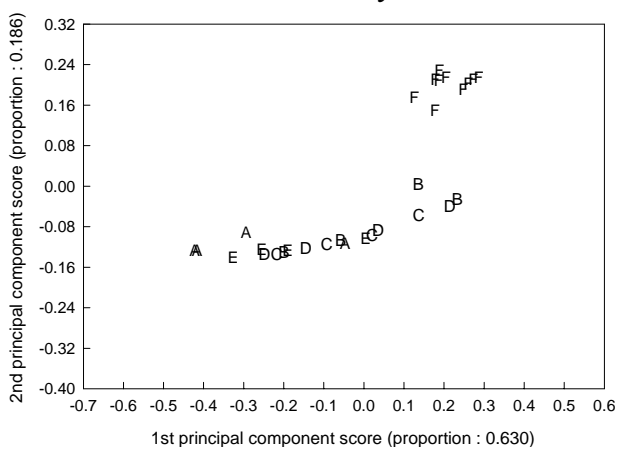

After 4 day

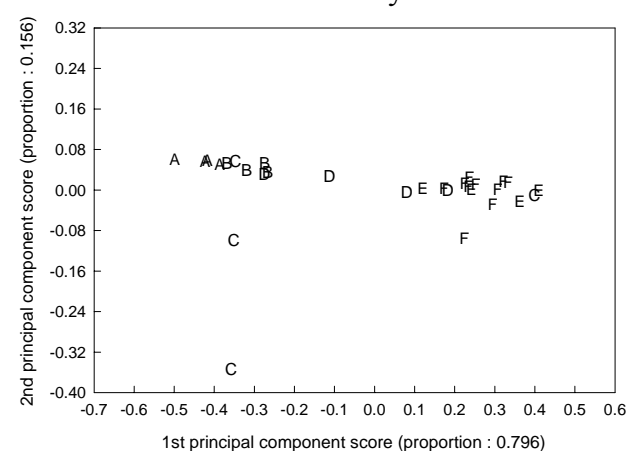

After 8 day

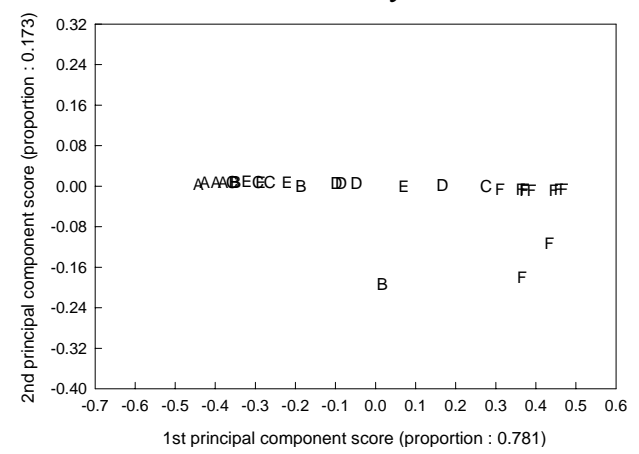

Fig. 2. Principal component analysis of Pleurotus ostreatus stored at $5^{\circ} \mathrm{C}$.

A: control (MAP mushroom without treatment), B: MAP mushroom with Astemisia princeps dough, C: MAP mushroom with Astemisia capillaries dough, D: MAP mushroom with green tea dough, E: MAP mushroom with charcoal, F: Fresh mushroom. 
ferent levels among groups. Fig. 2 showed the first principal component in mushroom packed with green tea dough, and control had a positive value whereas mushrooms packed with Artemisia princeps or Artemisia capillaries dough or activated charcoal had negative values after 2 days storage. After 4 days, the PCA plot of fresh mushroom was placed on the right side and control on the left side and that of mushroom packed with treatment was located between the fresh mushrooms and control, and changes appearance were observed during storage at $5^{\circ} \mathrm{C}$.

The results suggested that the strong flavors of Artemisia princeps, Artemisia capillaries masked the off-flavor of MAP mushroom, and that green tea and activated charcoal might remove the off-flavor by adsorbing ethanol and acetaldehyde which are known to produce off-flavor.

Kee and Park (21) reported that activated charcoal added to onion juice might remove onion flavor by absorbing volatile flavor compounds in onion. Asao and Wang (22) also reported the charcoal particles combined with $\mathrm{H}_{3} \mathrm{PO}_{4}$ removed ammonia and trimethylamine odors. In addition, Urabe et al. (20) reported that green tea was exhibited deodorant activity against methylmercaptan that was the specifically offensive main volatile of porcine small intestines used as a human food.

\section{Weight loss}

The weight loss in mushrooms is due to moisture loss by diffusion through the film and respiratory substrates loss by respiration. Fig. 3 shows the differences in the weight loss between mushrooms packed with treatment and without treatment during storage. All groups lost weight during the storage, but weight loss of all groups (including control) was less than $1 \%$ at $20^{\circ} \mathrm{C}$ and $0.6 \%$ at $5^{\circ} \mathrm{C}$. There were no significant differences among control and treatments, but the storage temperature of $20^{\circ} \mathrm{C}$ or $5^{\circ} \mathrm{C}$ did have an effect. The results showed an effect of modified atmosphere (MA) that decrease transpiration rate and respiration activity by modified gas content in bag.

Loss of $3 \sim 6 \%$ of weight of fresh vegetable and fruit is usually enough to cause a marked deterioration of quality for most kinds of products and for mushrooms the acceptable weight loss is about $2 \%(13,23)$.

\section{Package atmosphere}

Fig. 4 shows the changes in $\mathrm{CO}_{2}$ and $\mathrm{O}_{2}$ concentration in the PE film bag. The $\mathrm{CO}_{2}$ concentration in the bag increased rapidly, between $11 \%$ and $13 \%$, within 1 day at $20^{\circ} \mathrm{C}$ and 2 days at $5^{\circ} \mathrm{C}$, in all groups regardless of treatments. The $\mathrm{O}_{2}$ concentration decreased to $1 \%$ and remained at less than $1 \%$ throughout storage.

Some authors have reported an optimum in-package $\mathrm{O}_{2}$ concentration of $1 \%$ without creating anaerobic conditions (3), and that the accumulation of $\mathrm{CO}_{2}$ inside the mushroom package can also prevent deterioration. On the other hand, excessive accumulation of $\mathrm{CO}_{2}(>20 \%)$ inside package can have a damaging effect, producing ethanol and acetaldehyde as well as potential growth of anaerobic pathogens causing anaerobic respiration (3, $6,14,23)$. In our case, the off-flavor was detected in the mushrooms stored in packages and it was believed to
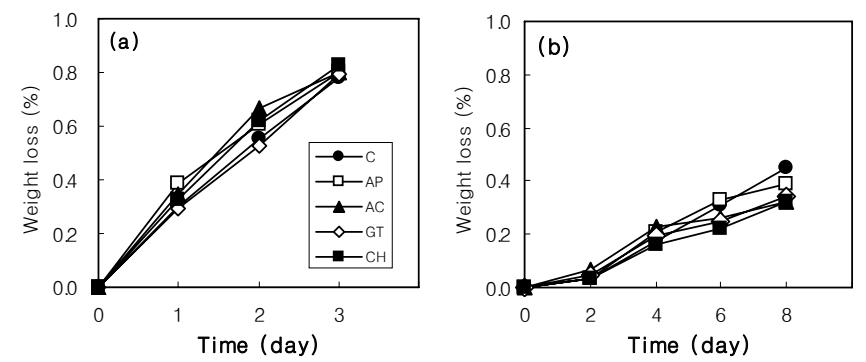

Fig. 3. Changes in weight loss (\%) in modified atmosphere packaged (MAP) Pleurotus ostreatus during storage at 20 (a) and $5^{\circ} \mathrm{C}(\mathrm{b}) . \mathrm{C}$ : control (MAP mushroom without treatment), AP: MAP mushroom with Astemisia princeps dough, AC: MAP mushroom with Astemisia capillaries dough, GT: MAP mushroom with green tea dough, $\mathrm{CH}$ : MAP mushroom with charcoal.

$\mathrm{CO}_{2}$ concentration
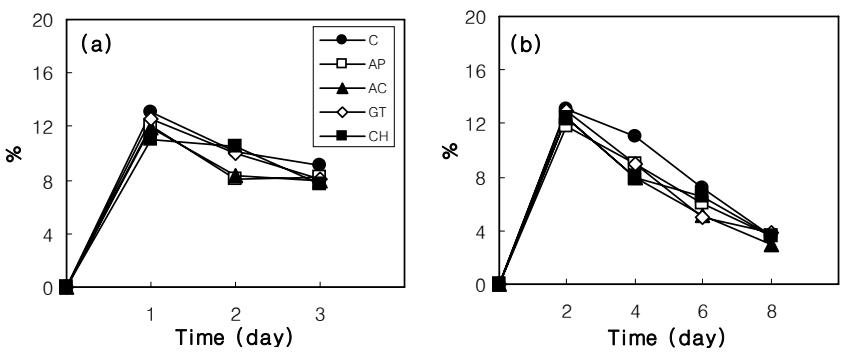

$\mathrm{O}_{2}$ concentration
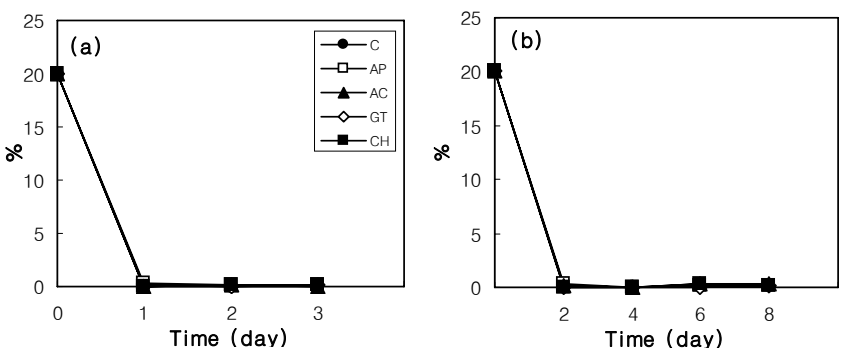

Fig. 4. Changes in packaging atmosphere of modified atmosphere packaged (MAP) Pleurotus ostreatus during storage at 20 (a) and $5^{\circ} \mathrm{C}$ (b). C: control (MAP mushroom without treatment), AP: MAP mushroom with Astemisia princeps dough, AC: MAP mushroom with Astemisia capillaries dough, GT: MAP mushroom with green tea dough, $\mathrm{CH}$ : MAP mushroom with charcoal. 
Table 1. Changes in color (Hunter $\mathrm{b}$ value) of MAP Pleurotus ostreatus

\begin{tabular}{ccccccc}
\hline \multirow{2}{*}{ Temperature } & $\begin{array}{c}\text { Storage time } \\
\text { (days) }\end{array}$ & C & AP & TC & GT & CH \\
\cline { 3 - 6 } & 0 & 16.65 & 16.65 & 16.65 & 16.65 & 16.65 \\
\multirow{2}{*}{$20^{\circ} \mathrm{C}$} & 1 & $17.73^{\mathrm{ab}}$ & $16.39^{\mathrm{a}}$ & $18.76^{\mathrm{b}}$ & $18.30^{\mathrm{b}}$ & $18.64^{\mathrm{b}}$ \\
& 2 & $19.76^{\mathrm{a}}$ & $18.93^{\mathrm{a}}$ & $18.59^{\mathrm{a}}$ & $19.65^{\mathrm{a}}$ & $19.40^{\mathrm{a}}$ \\
& 3 & $20.88^{\mathrm{b}}$ & $19.86^{\mathrm{ab}}$ & $18.40^{\mathrm{a}}$ & $20.49^{\mathrm{b}}$ & $19.21^{\mathrm{ab}}$ \\
\hline \multirow{2}{*}{$5^{\circ} \mathrm{C}$} & 0 & 16.65 & 16.65 & 16.65 & 16.65 & 16.65 \\
& 2 & $17.62^{\mathrm{a}}$ & $18.51^{\mathrm{a}}$ & $18.77^{\mathrm{a}}$ & $17.57^{\mathrm{a}}$ & $17.52^{\mathrm{a}}$ \\
& 4 & $17.67^{\mathrm{a}}$ & $17.14^{\mathrm{a}}$ & $19.15^{\mathrm{a}}$ & $19.17^{\mathrm{a}}$ & $17.55^{\mathrm{a}}$ \\
& 6 & $18.78^{\mathrm{a}}$ & $19.03^{\mathrm{a}}$ & $19.99^{\mathrm{a}}$ & $19.51^{\mathrm{a}}$ & $19.21^{\mathrm{a}}$ \\
& 8 & $19.79^{\mathrm{a}}$ & $19.79^{\mathrm{a}}$ & $19.64^{\mathrm{a}}$ & $19.69^{\mathrm{a}}$ & $19.86^{\mathrm{a}}$ \\
\hline
\end{tabular}

${ }^{1)} \mathrm{C}$ : control (MAP mushroom without treatment), AP: MAP mushroom with Astemisia princeps dough, AC: MAP mushroom with Astemisia capillaries dough, GT: MAP mushroom with green tea dough, ${ }^{2} \mathrm{CH}$ : MAP mushroom with charcoal.

${ }^{\mathrm{a}, \mathrm{b}}$ Means (the average of ten replicates) within the same row bearing the same superscript are not significantly different $(\mathrm{p}<0.05)$.

be caused by anaerobic respiration. The $\mathrm{CO}_{2}$ concentration decreased gradually after reaching a peak by 24 hours of storage (Fig. 4). According to Lee (24), this appearance was considered to be a consequence of film permeability characteristics-OTR (oxygen transfer rate), CTR (carbon dioxide transmission rate).

\section{Color}

Duckworth and Coleman (25) observed that the activity of tyrosinase, responsible for mushroom browning was depending on $\mathrm{O}_{2}$ concentration. The yellowness of mushrooms during storage is shown in Table 1 . At $5^{\circ} \mathrm{C}$, the $b$ value (yellowness) was generally increased from 16.65 , initial $b$ value of fresh mushrooms before storage. At $20^{\circ} \mathrm{C}$, the $\mathrm{b}$ value of $\mathrm{AC}$ dough treatment increased less comparing to others.

\section{Quality evaluation}

Bacterial growth on the surface and internal tissue of freshly harvested mushrooms is a cause of deterioration during post harvest storage (26). Fig. 5 shows the changes in the extent of contamination in modified atmosphere packaged mushrooms during storage. At $20^{\circ} \mathrm{C}$, the mushrooms packed with Artemisia princes (AP) or Artemisia capillaries (AC) dough exhibited little microbial contamination (the score of $\mathrm{AP}$ and $\mathrm{AC}$ treatment was 4.76 and 4.86, respectively) while the mushroom packed with green tea (GT) dough, activated charcoal $(\mathrm{CH})$ and without treatment had severe microbial contamination (the score of GT, CH and control was 2.76, 2.79 and 2.78, respectively). For that reason, the mushrooms packed with green tea (GT) dough, activated charcoal $(\mathrm{CH})$ and without treatment lost their value as commodities after 3 days. At $5^{\circ} \mathrm{C}$, the sensory score of treatment groups as compared with that of control were high. After 8 days, the scores of control, AP, AC, GT and $\mathrm{CH}$ were $3.86,4.10,4.31,4.36$ and 4.40 , respectively. These results showed that the microbial contamination
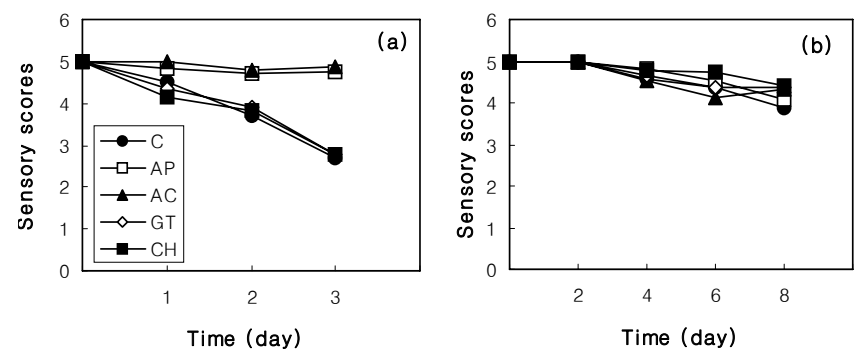

Fig. 5. Changes in sensory score (microbial contamination) of MAP Pleurotus ostreatus during storage at 20 (a) and $5^{\circ} \mathrm{C}$ (b). C: control (MAP mushroom without treatment), AP: MAP mushroom with Astemisia princeps dough, AC: MAP mushroom with Astemisia capillaries dough, GT: MAP mushroom with green tea dough, $\mathrm{CH}$ : MAP mushroom with charcoal.

of mushrooms during storage was effected by temperature and kinds of treatments. In the case of storage temperature, the higher temperature was, the greater the microbial contamination. On the other hand, treatment with Artemisia princeps (AP) and Artemisia capillaries (AC) showed antimicrobial activity regardless of storage temperature and that of green tea (GT) dough and activated charcoal $(\mathrm{CH})$ were more effective at $5^{\circ} \mathrm{C}$. But there were no statistically significant differences among the treatments.

The inhibition of microbial activity has previously been reported for Artemisia species (27-29). Lee and Seo (28) reported the acetone extracts of Artemisia capillaries showed antibacterial activity against food-borne pathogens and Cho et al. (29) reported that antibacterial constituents were isolated from whole Artemisia princeps. It showed a clear inhibitory effect against human intestinal bacteria. Fabien et al. (30) also reported that the essential oil of the aerial parts of Artemisia annua, consisting of camphor $(44 \%)$, germacrene D (16\%), trans-pinocarveol (11\%), $\beta$-selinene (9\%), $\beta$-caryophyllene (9\%) and artemisia ketone (3\%), was screened for its antimicrobial activity and remarkably inhibited the growth 
of tested gram-positive bacteria and fungi.

It has also been reported green tea exhibits antimicrobial effects as well as deodorization activities (20). Polyphenols and extract of green tea have been shown to have antibacterial activities against disease-related bacteria (31) and food-borne bacteria (32).

In our study, Artemisia princeps and Artemisia capillaries dough exhibited the strongest antimicrobial properties when packed with mushrooms. These results showed that the contamination of mushroom was effected by storage temperature and treatments.

\section{CONCLUSION}

The biochemical changes and occurrence of off-flavor were observed in mushrooms packed with treatments (AP, AC, GT dough and $\mathrm{CH}$ ) and without treatment. No differences in weight loss, gas concentration or color were found between mushrooms packed with and without treatment. However, the principal component analysis (PCA) using the electronic nose showed the differences in principal components between control and treatment group at $5^{\circ} \mathrm{C}$. This result demonstrated that Artemisia princeps, Artemisia capillaries masked the off-flavor of MAP mushroom, due to their strong characteristic flavors. The results also suggested that green tea and activated charcoal might have a role in removing the off-flavor by adsorbing ethanol and acetaldehyde, which is known as the component of off-flavor. The sensory result revealed that Artemisia princeps and Artemisia capillaries treatment inhibited microbial growth in mushrooms.

\section{ACKNOWLEDGEMENT}

This work was partially supported by the Korea Research Foundation Grant funded by the Korean Government (MOEHRD) (KRF-2005-005-J13001).

\section{REFERENCES}

1. Hamuro J, Chihara G. 1984. Immunomodulation agents and their mechanism. Fenichel RL, Chirigos MA, eds. Marcel Dekker, New York. p 409.

2. Chihara G, Hamuro J, Maeda YY, Arai Y, Fukuoka F. 1970. Fractionation and purification of the polysaccharides with marked antitumor activity, especially Lentinan from Lentinus edodes (Berk) Sing (an edible mushroom). Cancer Res 30: 2776-2781.

3. Kader AA, Zagory D, Kerber EL. 1989. Modified atmosphere packaging of fruits and vegetables. CRC Crit Rev Food Sci Nutr 28: 1-30.

4. Anantheswaran RC, Beelman RB. 1995. Fresh mushroom quality as affected by modified atmosphere packaging. $J$ Food Sci Nutr 60: 334-340.
5. Roy S, Anantheswaran RC, Beelman RB. 1996. Modified atmosphere and modified humidity packaging of fresh mushrooms. J Food Sci 61: 391-397.

6. Lopez-Briones G, Varoguaux P, Chambroy Y, Bouquant J, Bureau G, Pascat B. 1992. Storage of common mushroom under controlled atmosphere. Int J Food Sci Technol 27: 493-505.

7. Gormley TR. Chill storage of mushroom. J Sci Food Agric 26: 401-411.

8. Hershko V, Nussinovitch A. 1998. Relationships between hydrocolloid coating and mushroom structure. J Agric Food Chem 46: 2988-2997.

9. Lescano G. 1994. Extension of mushroom (Agaricus bisporus) shelf life by gamma radiation. Postharvest Biol Technol 4: 255-260.

10. Escriche I, Serra JA, Gomez M, Galotto MJ. 2001. Effect of ozone treatment and storage temperature on physicochemical properties of mushrooms (Agaricus bisporus). Food Sci Tech Int 7: 251-258.

11. Roy S, Anantheswaran RC, Beelman RB. 1995. Sorbitol increases shelf life of fresh mushrooms stored in conventional packages. J Food Sci 60: 1254-1259.

12. Anantheswaran S, Sunkara R. 1996. Use of commercial moisture absorbers to increase the shelf life of fresh mushrooms. Americarn Mushroom Institute 12: 24-26.

13. Sveine E, Klougart A, Rasmussen CR. 1967. Ways of prolonging the shelf life of fresh mushrooms. Mushroom Sci 6: 463-474.

14. Nicholas R, Hammend JBW. 1973. Storage of mushrooms in pre-packs the effect of changes $\mathrm{n}$ carbon dioxide and oxygen on quality. J Sci Food Agric 24: 1371-1381.

15. Minamida T, Tsuruta M, Ogata K. 1980. Studies on keeping freshness of Shiitake mushroom (Lentinus edodes) after harvest. J Japan Food Sci Technol 27: 26-30.

16. Lee SE, Kim DM, Kim KH. 1991. Changes in quality of Shiitake mushroom (Lentinus edodes) during modified atmosphere (MA) storage. J Korean Soc Food Nutr 20: $133-138$.

17. Villaescusa R, Gil MI. 2003. Quality improvement of Pleurotus mushrooms by modified atmosphere packaging and moisture absorbers. Postharvest Biol Technol 28: 169-179.

18. Wilkes JG, Conte ED, Kim YK, Holcomb M, Sutherland JB, Miller DW. 2000. Sample preparation for the analysis of flavors and off-flavors in foods. J Chromatography 880: 3-33.

19. Ku KH, Kim YJ, Koo YJ, Choi IU. 1999. Effects of pre-treated sub-ingredients and deodorization materials on the kimchi smell during fermentation. Korean J Food Sci Technol 31: 1549-1556.

20. Urabe K, Nadamoto T, Kawamura M, Yasumoto K. 1994. Effects of Houttuyniae cordata and refinery final molasses on the development of offensive odor in porcine small intestine during storage. J Nutr Sci Vitaminol 40: 63-71.

21. Kee HJ, Park YK. 1999. Effect of seaweeds and adsorbents on volatile flavor components of onion juice. Korean J Food Sci Technol 31: 1477-1483.

22. Asao O, Wang GI. 2002. Deodorization performance of charcoal particles loaded with orthophosphoric acid against ammonia and trimethylamine. Carbon 40: 13911399.

23. Beit-Halachmy I, Mannheim CH. 1992. Is modified atmosphere packaging beneficial for fresh mushrooms. Technol 25: 426-432

24. Lee JS. 1999. Effects of modified atmosphere packaging 
on the quality of chitosan and $\mathrm{CaCl}_{2}$ coated mushroom (Agaricus bisporus). Korean J Food Sci Technol 31: 1308-1314.

25. Duckworth HW, Coleman JE. 1970. Physicochemical and kinetic properties of mushroom tyrosinase. $\mathrm{J}$ Biol Chem 245: 1613-1625.

26. Guthrie BD. 1984. Studies on the control of bacterial deterioration of fresh, washed mushrooms (Agaricus bisporus/ brunescens). MS Thesis. Pennsylvania State University, USA.

27. Deans S. 1990. Essential oil profiles of several temperate and topical aromatic plants: their antimicrobial and antioxidative properties. Proceedings of the 75 th International Symposium of the Research Institute for Medicinal Plants. Budakalsz, Hungary.

28. Lee CK, Seo JJ. 2003. Antimicrobial activity of the aerial part of Artemisia capillaries extracts on the food-borne pathogens. J Korean Soc Food Sci Nutr 32: 1227-1232.

29. Cho SH, Na YE, Ahn YJ. 2003. Growth inhibiting effects of seco-tanapartholides identified in Artemisia princeps var. orientalis whole plant on human intestinal bacteria. J Appl Microbiol 95: 7-12.

30. Fabien J, Veronuque M, Jean MB, Michel D, Josette V. 2002. Antibacterial and antioxidant activities of Artemisia annua essential oil. Fitoterapia 73: 532-535.

31. Sakanaka S, Kim M, Taniguchi M, Yamamoto T. 1989 Antibacterial substances in Japanese green tea extract against Streptococcus mutans, a cariogenic bacterium. Agric Biol Chem 53: 2307-2311.

32. Hara Y, Ishigami T. 1989. Antibacterial activities of tea polyphenols against food-borne pathogenic bacteria. Nippon Shokuhin Kokyo Gakkaishi 36: 996-999.

(Received September 10, 2007; Accepted December 3, 2007) 